\title{
Economics of Education: An Idea for a Poor Nation
}

\author{
Abul K. Azad ${ }^{1 *}$ \\ ${ }^{1}$ Uniting World, Sydney, Australia \\ *Abul K. Azad, E-mail: kazad9@gmail.com
}

\begin{abstract}
Bangladesh has been beset with manifold everyday problems even after becoming a lower middle-income country in 2015. This paper argues that the huge population is a key problem in this country and the existing higher education at general universities and colleges is generally unproductive. Against this backdrop, this study suggests that the country's population problem can be transformed into human resources by introducing a purposeful higher education system. The purposeful education will have three broad-based impacts on the society. First, wastage of education will be minimised and efficiency will go up as people will get a job matching their skills they gain from their study. Second, there will be less possibility of unemployment as students will be provided with skills related to the demands of local and foreign job markets, and the governmental will help them secure jobs. Third, the existing size of the population will go down significantly in line with the students moving abroad with jobs in a revolutionary way, which could revolutionise the country's socioeconomic condition.
\end{abstract}

\section{Keywords}

Bangladesh, economics, education, skill, employment, development

\section{Introduction}

Bangladesh is a South Asian country that won independence from Pakistan in 1971 (see Table 1 that provides some relevant data about Bangladesh). This is one of the densely populated (World Atlas, n.d.) and least developed countries (WTO, n.d.) in the world, although it has become a lower middle-income country from the low-income group of countries in 2015 (World Bank, n.d.). It has been beset with manifold everyday problems such as a horror of deteriorating law and order situation, a high record of rampant road mishaps and traffic jams, the supply of adulterated foods, air and noise pollution, and crises of drinking water and electricity (Jamaluddin, 2012). These problems apparently post that there has been no development work in the country for the last 46 years since its independence. But, in fact, it is generally observed that all most all the sectors have achieved more or less progress so far. For example, food production, electricity generation and distribution, gas extraction and distribution, gross national income, the rate of literacy, communication facilities, building construction, and the number of law enforcing agencies and their personnel have gone up in comparison with those of the first decade of the independence. So, where have theses development outputs gone? Apparently, the increasing population, which has more than doubled over the period to 156,186,882 (CIA, n.d.), has somehow 
been eating up the achievements. So, the country's population seems to be a major stumbling block. However, it could still be a question: Is the population a problem or wealth? A number of global organisations (e.g., The World Bank, 2002; UNDP, 1999) opined that Bangladesh needs to utilise its population by providing them with proper education and training on an emergency basis. Have the population in Bangladesh been educated in a right way yet? Are there general relationships between educational course curricula and employments? Do the students generally secure jobs that relate to their skills they gain in their study programmes? Although some works (e.g., Islam \& Mia, 2007; Alam, 2008; Masum, 2008; Alam, 2009; Alam et al., 2009) on the education of the country have touched these issues, no one has come up with what skills the students generally gain and what they do with that after finishing their study programmes, and what actually is needed to do in the country's education and other sectors for appropriate utilisation of the county's vast population. This article looks for answers to these questions first and then suggests a new type of higher education to this effect.

\section{Table 1. Bangladesh at a Glance}

- Location: South Asia, bordering the Bay of Bengal, Myanmar (271 km) and India (4,142 km)

- History: Muslim conversions and settlement in the region started in the 10th century. Europeans established trading posts in the area in the 16th century. Eventually, the area known as Bengal became a part of British India and then Pakistan in 1947. It became independent Bangladesh in 1971 by winning a bloody war against Pakistan with all-out supports from India.

- $\quad$ Ethnicity: Bengali 98\%, others $1.1 \%$

- $\quad$ Language: Bangla 98.8\%, others $1.2 \%$

- $\quad$ Population size: $156,186,882$

- $\quad$ Religion: Muslim 89.1\%, Hindu 10\%, others 0.9\% (including Buddhist and Christian)

- $\quad$ Rate of literacy: $61.5 \%$

- $\quad$ Rate of enrolment in higher education: $13.23 \%$

- $\quad$ Rate of enrolment in secondary education: $52 \%$

- $\quad$ Rate of enrolment in primary education: $98 \%$

- $\quad$ Rate of graduate unemployment: $47 \%$

- $\quad$ Labour force: 83.59 million

- $\quad$ Extensive export of labour to Saudi Arabia, Kuwait, UAE, Oman, Qatar, and Malaysia

- $\quad$ Workers' remittances were \$15 billion in 2015 (8\% of GDP).

- About $40 \%$ of the population is underemployed; many persons counted as employed work only a few hours a week and at low wages.

Sources: CIA, n.d.; World Bank Indicator, n.d.; World Bank Education, n.d.; EIU_British_Council, 2014; ICEF, n.d. 


\section{Methodology and Study Plan}

It is needless to say that population is one of the precious natural resources like gold, gems or petroleums. These mineral items are not useful until they get processed in a right way. Accordingly, a human is unemployed until he or she is educated or trained decisively to perform certain duties. One mineral item is processed to make various kinds of items with little differences, such as petrol, diesel, and engine oil are made from the same mineral oil according to demands of markets. The same way and for the same reason for marketing, different types of ornaments are made from gold. The population is also used for carrying out various types of jobs by providing them with particular education and training following the demands of the job markets. And, the market does not mean only local market; it is actually both local and foreign or international markets. The above ideas about population, education and job markets are used in this study.

Historical observational approaches are applied to this research. I was born in Bangladesh and went to all general categories of educational institutions-primary school, secondary school, college and a general public sector university of the country. Also, I competed in the country's traditional job market and worked in the education system for seven years from 1996 to 2003. I moved to New Zealand in 2003 and did my PhD and then worked till 2013, and am currently working in Australia. Besides, since 1991, I have been associated with journalism, Op-Ed writing and, later, research on Bangladesh affairs including education. Whatever I say in this paper are based on my personal experiences and observation in Bangladesh and New Zealand, and my studied secondary data.

At first, the country's longstanding common problems such as rampant road mishaps and traffic jams, the supply of adulterated foods, air and noise pollutions, crises of drinking water, electricity and gas, and deteriorating law and order are observed, and then these sectors' development histories are looked at. It is found that all the problems surprisingly continued even after a more or less development had taken place in the same sectors. When the growth of population is observed, it is found that the increasing population has eaten up the development outputs. As a result, the problems have continued, and the population is to blame for all the problems. On the other hand, the general education at its higher level and/or recruitment system are found faulty as a huge section of the population has been unemployed, and even employed people have not gotten jobs matching their skills they had gained from their educational courses. On this back, an idea of purposeful education is recommended in the later part of this article with a view to transforming this society into a better one. However, this study does not cover the area of job creation.

\section{Observation of Existing Education}

Education in Bangladesh can primarily be divided into two stages: basic stage and higher stage. The basic stage is up to the schooling Year 12. Primary schools, kindergartens, junior high schools, high schools, English medium schools, vocational institutes and madrassahs (Islamic religious schools) provide basic education at this stage. Students in general gain basic knowledge of mathematics, English

Published by SCHOLINK INC. 
and Bengali languages and literature, society, sciences, and technologies, among others, at this stage (BANBEIS, n.d.). I call it "basic education stage" as it is actually required for higher education and lower-level jobs.

The higher stage of education that includes bachelor, masters and doctoral qualifications starts when the basic education stage ends. Universities, some university colleges (Note 1), institutes and madrassahs provide these categories of education which may be broadly classified as general education and technical education. Technical education here comprises different categories of medical and engineering disciplines such as medicine, optometry, dentistry; civil, electrical and mechanical engineering, leather and textile technologies, and Information Communication Technologies (ICT). Technical education is generally taught at different specialised institutions like engineering universities, medical colleges, and leather and textile technology institutes. General education includes all the arts, science, social science and commerce which are generally taught under three-to-four-year bachelor and one-to-two-year masters programmes (BANBEIS, n.d.). The number of students doing general qualifications is manifold higher than those doing technical qualifications (Islam \& Mia, 2007; Alam, 2009) and most of them are at general universities and university colleges in the public sector.

Generally, low-calibre students eventually become teachers in general educational institutions in Bangladesh. Long time back, university teachers used to be recruited generally on the basis of the candidates' relationship with existing senior teachers after meeting officially set eligibility criteria. At the current age, liking or disliking of ruling political party allegedly plays a vital role in the recruitment process. Government college teachers are recruited at the entry level through competitive examinations administered by a constitutional body, Bangladesh Public Service Commission (BPSC), but applicants generally take this Education Cadre job as the last option, although all Cadre jobs such as police, administration, foreign affairs, and taxation have the same rank and salary. At private colleges and schools, people generally accept a teaching job as a last resort in their drive to get employed. It is learnt that once male applicants for private college jobs had to marry relative girls of the heads of the college governing bodies. Nowadays, this recruitment is done under the authority of a Member of Parliament and allegedly in exchange for millions of Taka, the Bangladesh currency (Education: MP style, Sept 26, 2011).

\section{Output of Existing Higher Education}

So far, this country has experienced a number of education reform commissions and their policies, for example, Qudrat-e-Khuda Education Commission soon after the country's independence, Majid Khan's education policy during the military regime in the 1980s and the 2010 National Education Policy. But it is observed that all the education policies adopted in Bangladesh so far are by and large identical as all of these have bred millions of educated unemployed, and the total employment of Bangladeshis at home and foreign job markets has not improved significantly (Banglapedia, n.d.). The changes in education policies have basically focused on different political and cultural objectives, rather than

Published by SCHOLINK INC. 
employment.

It is observed that the basic education (up to Year 12), and a few higher education programmes including medicine, engineering, ICT, textile and leather technology are generally on right and acceptable track as whatever is taught in these areas is normally useful in securing a job and performing the duties. However, with a few exceptions, subjects taught in normal bachelor, bachelor with honours and masters degree programmes at general universities and colleges generally have no relationships with employment. As a result, a huge number of so-called educated people add to the list of the country's unemployed population every year. Only a section of educated people gets jobs and work in different cadres of Bangladesh Civil Service (BCS), educational institutions including private colleges, non-government organisations, and various types of private companies. In those jobs, other than in professional cadres like education and judiciary, and some other jobs like accounting and ICT, it is quite hard to find any relationships between taught subjects or courses and employments or nature of work. For example, students of international relations are supposed to have a good grasp of knowledge about foreign affairs, but it is observed that the English literature students dominate the BCS foreign affairs cadre. About government administration, no students are supposed to have better knowledge than the ones of public administration, political science and law but their presence in this cadre is negligible. Besides, it is personally known to me that some people who studied MBBS have worked in foreign affairs and administration cadres and some others after learning chemistry for years in bachelor (honours) and masters programmes have carried out the BCS Police cadre job. So, what is the contribution of educational institutions to the employment of their students? Yes, one visible contribution of the institutions is that they grade the students and confer certificates which are required for job applications. At this point, the question is that why the educational institutions take years to grade and give away certificates instead of conducting a one-hour grading test since what they teach results in almost nothing in terms of employment. A positive answer to this question may be that there is a relationship between the taught courses in higher education and employment of teachers for the same programme and the same subject. Explaining the relationship, one can say that general universities and, in some cases, university colleges produce teachers for higher education for the same courses. However, in this case too, I would like to dub this teacher production as an unproductive production since teachers produce just teachers in a cyclic order; what courses they learn and teach have no relationships with employments other than such teaching jobs in general. Moreover, the importance of a university lies in research, but it is quite hard to see any general university coming up with any research work to help resolve any problem in this country of thousands of problems.

In fact, students of general universities and university colleges either do not get jobs matching their qualifications or even if they get jobs, their job descriptions do not match what skills they gain in their educational programmes. So, such higher education results in wastage of education, wastage of money from both government coffers and pockets of students' parents, and wastage of students' time and energy as well. Therefore, the question of the hour is that why such a poor country spends huge Published by SCHOLINK INC. 
amounts of money on an unproductive production every year.

\section{Suggestion: Purposeful Education}

What kind of education and employment system can ensure the appropriate use of population is actually the main issue of consideration. Based on this proposition, it is recommended in this paper that the whole higher education in the country should primarily be divided into two sectors: public and private. The public sector higher education will be divided into three categories: Education for mentors, Education for internal job markets and Education for external job markets (see Figure 1). The public sector higher education has to be purposeful in terms of employment and should gradually exclude the course curricula and programmes that do not have a relationship with securing employment and the nature of the work of employees. There should be efforts as much as possible to absorb the people working with traditional general higher education in the related departments of purposeful education. The private sector higher education providers may have some freedom to go by their own curricula so that there is a competition between public and private sectors. If they want, they should be allowed to provide traditional general education.

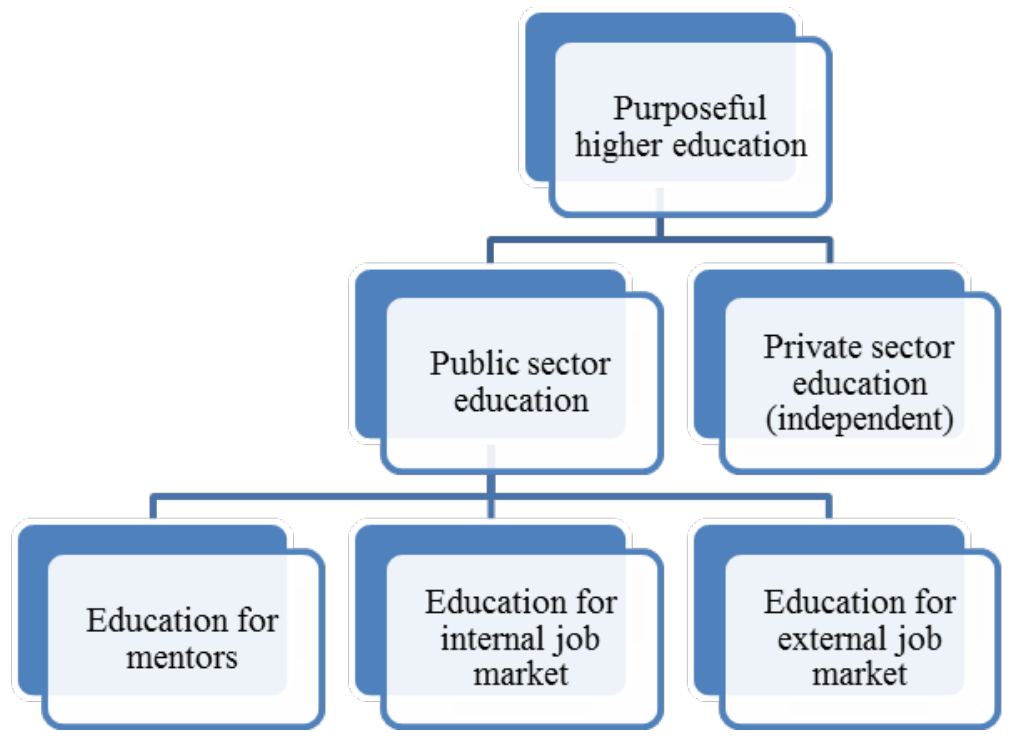

Figure 1. The Proposed Higher Education System

For the implementation of purposeful education, the government will provide students with an interest-free or low-interest loans covering tuition, and course-related, job search and relocation costs. Students will be allowed to repay their loans by easy instalment once they finish their education and start working. Every year or so, the government will explore the general possibilities of future employment opportunities at home and abroad by conducting research. Such research will look for answers to the questions like what type of and approximately how many workers or employees are needed and for what type of work. On the basis of the research findings, different educational Published by SCHOLINK INC. 
programmes, courses and subjects will be selected for student enrolment. Thus, appropriate manpower will be produced for meeting the demand in local and foreign job markets; skilled people will get jobs related to their areas of study.

The Education for mentors will cover all up-to-date and traditional courses and programmes that will produce just a pre-estimated number of experts and teachers. Those courses and programmes will be available to only a limited number of students who have exceptional talent, strong interest and integrity. The students with these qualities will come forward if research and teaching jobs are made the most lucrative by offering exceptionally higher salary, attractive facilities and practically admirable condition. The produced teachers and experts will teach the courses related to the internal and external job markets, conduct research and provide the country's policymakers with expert advice. Their research areas and topics will cover, among others, practical problems and their solutions such as production and distribution of food, electricity, gas, petroleum, water; safe and smooth transportation, the relationship between education and employment, job markets at home and abroad, human rights, law and order, scientific discoveries, technological inventions and their application, and foresighted national plans.

The Education for internal job markets will target both public and private sectors and all the work areas including the BCS cadre jobs. Every educational department will formulate their course curriculum and programmes following the job descriptions of the targeted positions. For example, the course curriculum of the Department of Public Administration at a university will focus on the job descriptions of BCS Administration cadre positions. Public sector employers will recruit the candidates who graduated from the departments or study programmes which are most relevant to the positions. Private sector employers should be allowed to enjoy freedom in hiring their staff members.

The main focus of the purposeful education will be on the Education for external job markets. This kind of drive will also have an ample opportunity to succeed as Bangladeshis are generally enthusiastic about working abroad and there are a number of countries which are big in terms of geographical area and resources, but quite small in terms of population, such as Australia and Canada. Western countries like Australia, United States of America, Canada, and New Zealand should get more priority than the traditional Middle Eastern and Arab job markets as wages and salaries are much higher in the West, and there are more social securities, opportunities for foreigners to settle permanently and some other attractions. This kind of welcoming situation generally attracts Bangladeshis, and they also have a dream of it, but many of the dreams do not come true chiefly due to a lack of appropriate higher education.

The government will tap the opportunities of demand for different categories of workers and professionals by using the popular enthusiasm about working abroad and by educating them appropriately. To this effect, the government primarily can set up Manpower Export Processing Zones (MEPZs) at all general universities and university colleges in the public sector. The MEPZs will be similar to existing Export Processing Zones (EPZ) for industrial products. At these MEPZs, courses and Published by SCHOLINK INC. 
programmes that include medicine, engineering, ICT, nursing, welding, plumbing, and many more like these may be taught to the international standards, according to the possible demands found in the studies on future external job markets. However, the qualifications in these courses and programmes will result in a zero on foreign job markets until the students are able to comfortably communicate in the first language of the countries where they want to work. So, some foreign languages such as English and Arabic will have to be compulsory for the MEPZ students.

It is necessary to note that many medical doctors, engineers and other highly qualified Bangladeshi immigrants struggle to find their professional work and have to do odd jobs such as driving taxies and picking apples in English-speaking western countries, whereas their education started in Bangladesh with English from Class One and continued for almost whole student life. Why is it? Actually, humans learn languages in two ways: Natural and artificial. The natural way, a child while growing up learns a language by viewing and listening from and mimicking to his or her mother, father, other family members and relatives. On the other hand, people learn a foreign language as their second language by studying grammar, reading literature, viewing movies, among others, in some artificial settings. However, no matter which process is employed, every language learner has to get skilled in four aspects of the particular language: Understanding by (1) reading and (2) listening, and making someone understand something by saying (3) orally and (4) in writing. These four aspects are not taught appropriate ways in the existing education system in Bangladesh, and this is why many educated Bangladeshis cannot communicate in English even after taking the lesson on English for almost of their whole life.

Day-by-day, the MEPZs will transform into manpower export processing industry. Then, one day, the government may have to urge all the active couples in the country to breed babies as many as they can and supply more raw materials (students) to this industry. There will be too many advantages of this kind of export industry compared to other export industries: Foreign money will come in a bigger way; gross national income will jump; living standard will improve; population will drop as MEPZ people will work, stay and settle abroad and, in line with this, traffic jam, household use of electricity and gas will decline. Besides, law and order will improve on the falling rate of unemployment. In fact, a comprehensive socioeconomic revolution is supposed to take place.

It is the fact that the implementation of purposeful education along with MEPZs will involve a huge amount of money which could not be met with the usual education budget of Bangladesh. So, where will the extra money come from? I hope finance will not be a big hurdle if such an educational project is clearly explained to the international lending organisations and donor countries that usually finance different mega projects in this country. Besides, this extra money could be collected by reducing the number and/or size of different future projects in power, gas, road communication and traffic, and law enforcing sectors as there will be no need to implement too many big projects in these sectors because it is already mentioned above that demand for power and gas, and problem of traffic jam will come down, and law and order could improve once the purposeful education is implemented and MEPZs Published by SCHOLINK INC. 
people start working abroad.

The purposeful education system can be implemented in phases. Among the three branches of purposeful education, the Education for external job markets could start in a year or two preparations at MEPZs with all the students of a batch who have just passed the Year 12 examinations with the top grade (GPA 5). And, this country can aim at reducing the total population to its half from the current 156 million (CIA, n.d.) by exporting from MEPZs in 15 to 20 years. Such huge exports from MEPZs and drastically dropped population could revolutionise the country's socioeconomic condition in different ways which are explained earlier. This kind of revolution is also believed to be able to blow out the longstanding political confrontation between two arch-rival political forces and unite the political-psychologically divided nation (Azad \& Crothers, 2012). Obviously, the implementation of the whole system of purposeful education will depend on a strong political sponsorship.

\section{Conclusion}

The purposeful education will have at least three broad-based impacts on the society. Firstly, wastage of education will be minimised, and workforce efficiency will go up as people will get a job matching their skills they gain from their study. Secondly, there will be less possibility of unemployment as students will be provided with skills related to the demands on local and foreign job markets, and government will help them secure jobs. Thirdly, the population will dip significantly in the country in line with the MEPZs students moving abroad with jobs in a revolutionary way, which could revolutionise the country's socioeconomic condition. Besides, it is not also totally impractical that the Education for mentors will one day help local researchers discover a habitable planet that might help reduce present Bangladesh population further.

However, it is expected that there would be some debates on the concept of purposeful education. Scholars could argue that what subjects are taught in Bangladesh are taught all over the world as well, especially in the developed world, and all the existing general education programmes are also branches of knowledge. The counterargument will be that a poor country like Bangladesh does not have to explore all the branches of knowledge until its socioeconomic condition improves to a certain level.

Besides, it is noted that this paper has a number of shortcomings. Notably, among the three categories of purposeful education, two categories: Education for internal job markets and education for mentors get considerably less focused here. Private sector education is also not discussed adequately. Secondly, the paper does not cover the detailed process of implementation of the purposeful education and new employment systems, and possible implications for these systems in the society. Especially, the implementation of the purposeful education could risk a significant number of jobs in the existing system, but this study does not explore the ways on how to avoid the possible job losses. Some of these limitations of the paper are due to space constraints and some are led by non-availability of data. So, these gaps are now open for future research. 


\section{References}

Alam, G. M. (2008). The role of technical and vocational education in the national development of Bangladesh. Asia-Pacific Journal of Cooperative Education, 9(1), 25-44.

Alam, G. M. (2009). The role of science and technology education at network age population for sustainable development of Bangladesh through human resource advancement. Scientific Research and Essay, 4(11), 1260-1270.

Alam, G. M., Khalifa, M. T. B., \& Shahjamal, M. (2009). Return from education system in Bangladesh: An investigation on comparative flashback scenario. African Journal of Business Management, 3(10), 567-575.

Azad, A. K., \& Crother, C. (2010). Bangladesh: An umpired democracy. Journal of Social and Development Sciences, 3(6), 203-213.

BANBEIS. (n. d). Retrieved June 24, 2012, from http://www.banbeis.gov.bd/es_bd.htm

Banglapedia. (n.d.). Unemployment. Retrieved March 21, 2017, from http://en.banglapedia.org/index.php?title=Education_Commission

CIA. (n.d.). The world factbook: Bangladesh. Retrieved April 28, 2017, from https://www.cia.gov/library/publications/the-world-factbook/geos/bg.html

Education MP style. (2011, September 26). The Daily Star. Retrieved February 28, 2017, from http://www.thedailystar.net/newDesign/news-details.php?nid=203960

EIU_British_Council. (2014). High university enrolment, low graduate employment: Analysing the paradox in Afghanistan, Bangladesh, India, Nepal, Pakistan and Sri Lanka. Retrieved June 4, 2017, from https://www.britishcouncil.in/sites/default/files/british_council_report_2014_jan.pdf

$\begin{array}{lllll}\text { ICEF. } & \text { (n.d.). } & \text { Retrieved } & \text { June } & \text { 4, 2017, }\end{array}$ http://monitor.icef.com/2015/10/bangladesh-struggling-to-keep-up-with-demand-for-higher-educat ion/

Islam, M. R., \& Mia, A. (2007). The role of education for rural population transformation in Bangladesh. Asia-Pacific Journal of Cooperative Education, 8(2), 1-21.

Jamaluddin, S. (2012). A litany of woes the government ignores. The Financial Express. Retrieved June 26, from http://www.thefinancialexpress-bd.com/more.php?date=2012-05-19\&news_id=130035

Masum, M. (2008). Higher education in Bangladesh: Problems and policies. Journal of the World Universities Forum, 1(5), 17-30.

United Nations Development Programme (UNDP). (1999). Human development report. New York: UNDP.

World Atlas. (n.d.). Countries of the world by highest population density. Retrieved May 10, 2017, from http://www.worldatlas.com/aatlas/populations/ctypopls.htm

World Bank Education. (n.d.) Retrieved June 4, 2017, from http://www.worldbank.org/en/results/2016/10/07/ensuring-education-for-all-bangladeshis

World Bank Indicator. (n.d.). Retrieved June 4, 2017, from 
http://data.worldbank.org/indicator/SE.SEC.NENR

World Bank. (2002). Economic growth and public policy: The East Asian miracle. Washington, DC: World Bank.

World Bank. (n.d.). Retrieved June 3, 2017, from https://datahelpdesk.worldbank.org/knowledgebase/articles/906519-world-bank-country-and-lendi ng-roups

WTO. (n.d.). Least developed countries. Retrieved May 22, 2017, from https://www.wto.org/english/thewto_e/whatis_e/tif_e/org7_e.htm

\section{Note}

Note 1. In this article, university college means a college where master's programmes are also taught. 